\title{
Potassium Fertilization Affects Floricane Mineral Nutrient Content, Growth, and Yield of Blackberry Grown in Brazil
}

\author{
Ivan dos Santos Pereira \\ Embrapa Clima Temperado, BR 392, km 78, Caixa Postal 403, Pelotas, RS, \\ Brazil 96010-971
}

Luciano Picolotto

Universidade Federal de Santa Catarina-Campus Curitibanos, Rod. Ulysses Gaboardi, km 3 Curitibanos-Caixa Postal 101, Curitibanos, SC, Brazil 89520-000

\begin{abstract}
Michél Aldrighi Gonçalves and Gerson Kleinick Vignolo
Universidade Federal de Pelotas-Faculdade de Agronomia Eliseu Maciel, Campus Universitário, Caixa Postal 354, Pelotas, RS, Brazil 96001-970
\end{abstract}

\section{Luis Eduardo Corrêa Antunes ${ }^{1}$ \\ Embrapa Clima Temperado, BR 392, km 78, Caixa Postal 403, Pelotas, RS, Brazil 96010-971}

Additional index words. Rubus, nutrition, K, vegetative growth, yield, leaf tissue analysis

\begin{abstract}
The objective of this study was to evaluate the floricane leaf nutrient content, vegetative growth, and yield of two blackberry (Rubus spp.) cultivars (Tupy and Xavante), in response to rate of potassium $(K)$ fertilization $(0.0,2.1,4.2,6.2$, or $8.3 \mathrm{~g} / \mathrm{plant}$ of $\mathrm{K})$. The research was conducted in a region of low chill (342 chill hours) in southern Brazil (lat. $31^{\circ} 40^{\prime} 46.98 \mathrm{~S}$, long. $\left.52^{\circ} 26^{\prime} 4.36 \mathrm{~W}\right)$, and soil with pH 5.9, organic matter (OM) $1.1 \%$ and $\mathrm{K} 58.0 \mathrm{~g} \cdot \mathrm{m}^{-3}$. In 2009, only calcium (Ca) and magnesium (Mg) leaf concentration were affected by $K$ application, and leaf $K$ level was considered below normal for blackberry in Brazil. In 2010 and 2011, leaf $K$ of blackberry in Brazil increased linearly in both cultivars with an increase in applied $K$. However, leaf $K$ of blackberry in Brazil only reached its recommended levels for optimal growth in 2010 with the application of 2.1 and $8.3 \mathrm{~g} / \mathrm{plant}$ of K for 'Tupy' and 'Xavante', respectively. In 2011, an antagonistic relationship was seen between leaf nitrogen $(\mathrm{N}) / \mathrm{K}$ and $\mathrm{K} / \mathrm{Ca}$ and $\mathrm{K} / \mathrm{Mg}$ ratios with increasing $\mathrm{K}$ rates, where increasing $K$ rates were accompanied by a linear decrease in the $N / K$ ratio and a linear increase in the $\mathrm{K} / \mathrm{Ca}$ and $\mathrm{K} / \mathrm{Mg}$ ratios. Micronutrients evaluated showed no significant response to applied rates of $K$. A decrease in floricane leaf concentration of phosphorus $(P)$, iron ( $\mathrm{Fe})$, manganese (Mn), and zinc ( $\mathrm{Zn})$ was also observed over years of the study. Potassium fertilization rates influenced the vegetative growth of blackberries. 'Tupy' showed increased cane density and pruning weights with increased rates of $K$ application up to $8.3 \mathrm{~g} / \mathrm{plant}$, whereas cane density was optimized in 'Xavante' at $4.2 \mathrm{~g} / \mathrm{plant}$. The fruit yield of 'Tupy' and 'Xavante' increased linearly with $K$ application per plant in all three years, indicating that $K$ fertilization may be limiting the yield potential of these cultivars. These results suggest that the current $K$ fertilizer recommendations may need to be increased for optimal production in Brazil.
\end{abstract}

Blackberry (Rubus spp.) production and consumption is increasing worldwide (Antunes et al., 2014; Fachinello et al., 2011; Strik et al., 2007; Strik and Finn, 2012). The increase in consumption is mainly due to the high antioxidant capacity

Received for publication 13 Mar. 2015. Accepted for publication 29 June 2015.

We acknowledge financial support from CAPES (Coordenação de Aperfeiçoamento de Pessoal de Nível Superior) and CNPq (Conselho Nacional de Desenvolvimento Científico e Tecnológico). ${ }^{1}$ Corresponding author. E-mail: luis.antunes@embrapa. br. of phenolic compounds present in fruits, substances that make blackberry a fruit with nutraceutical properties that can help fight degenerative diseases (Lee et al., 2012; Vizzotto et al., 2012). Moreover, blackberry attracts producers because it requires few pesticides (Antunes et al., 2010, 2014; Botelho et al., 2009), an aspect that favors the implementation of organic systems.

Although native species of the genus Rubus ( $R$. urticaefolius, $R$. erythroclados, $R$. brasiliensis, $R$. Sellowii, and $R$. imperialis) occur in Brazil, blackberry research did not gain importance until 1972 with the introduction of the cultivars Brazos, Cherokee, and
Comanche (Antunes, 2002). Since 1975, the EMBRAPA blackberry breeding program, in collaboration with the University of Arkansas, has released six blackberry cultivars: Ébano (1981), Negrita (1983), Tupy (1988), Guarani (1988), Caingangue (1992), and Xavante (2004). Tupy is the most grown blackberry cultivar in Brazil, and also the most common in Mexico, mainly for export to the United States. 'Tupy' is a low-chill, semierect, vigorous, and thorny plant which produces large fruits $(8$ to $10 \mathrm{~g}$ ) with soluble solid content between 8 and 10 'Brix. 'Xavante' is a low-chill, vigorous, erect, and thornless plant which produces medium size fruit $(6 \mathrm{~g})$ with a fruit soluble solids content around $8{ }^{\circ}$ Brix (Antunes, 2002; Raseira and Franzon, 2012).

Many have suggested that the growth of the blackberry market depends on the study of various aspects of the production system, especially plant nutrition (Antunes et al., 2014; Castaño et al., 2008; Pereira et al., 2013b; Strik and Finn, 2012). Knowledge of nutritional requirements, nutrient uptake, and the rate and application method of fertilization are fundamental to obtaining higher yields in blackberry (Castaño et al., 2008). However, little research has been done on fertility and nutrient requirements for blackberry production in Brazil, and therefore remains a major constraint toward improving productivity.

Potassium performs various structural and metabolic functions in the plant. It has an important role in regulating the $\psi_{\mathrm{S}}$ of cells, and thus acts as an activator of many enzymes involved in respiration and photosynthesis (Castaño et al., 2008). It is a nutrient used in large quantities, especially in situations of high productivity. Depending on the cultivar and weed management strategy, nutrient loss from the fruit and floricanes may vary between 36 and $84 \mathrm{~kg} \cdot \mathrm{ha}^{-1}$ of $\mathrm{K}$ (Harkins et al., 2014). As the need is greatest during fruiting, $\mathrm{K}$ deficiency is common in years of high production, with symptoms including reduced growth, followed by chlorosis and necrosis in the leaves, and shortening of the internodes (Antunes et al., 2014; Castaño et al., 2008; Pereira et al., 2011). According to Pereira et al. (2013a), in an experiment where $\mathrm{N}$ was not evaluated, $\mathrm{K}$ was the element with the greatest uptake in 'Tupy' and 'Xavante' blackberries, with 6.8 and 5.4 $\mathrm{kg} \cdot \mathrm{t}^{-1}$ of fruit, respectively. In addition, $\mathrm{K}$ may influence fruit size, sugar content, and fruit firmness (Castaño et al., 2008; Hart et al., 2006; Rincon and Salas, 1987).

In blackberry, $\mathrm{K}$ is commonly provided by potassium chloride $(\mathrm{KCl})$, potassium sulfate, or potassium nitrate (Hart et al., 2006). $\mathrm{KCl}$ is usually less expensive, but high rates of chloride can be harmful. Maintenance fertilization with $\mathrm{K}$ should be applied in the spring, before budbreak and flowering (Freire, 2007; Crandall, 1995).

In Brazil, recommended $\mathrm{K}$ rates range from 0 to $66.7 \mathrm{~kg} \cdot \mathrm{ha}^{-1}$, depending on the nutrient content of the soil (CQFS-RS/SC, 2004). Typically, soils show low or medium levels, and therefore the recommended rates 
are between 33 and $66.7 \mathrm{~kg} \cdot \mathrm{ha}^{-1}$ of $\mathrm{K}_{2} \mathrm{O}$. In contrast, recommended rates of $\mathrm{K}$ fertilization in the United States may be as high as $112 \mathrm{~kg} \cdot \mathrm{ha}^{-1}$, depending on soil and primocane tissue K (Hart et al., 2006).

This study aimed to evaluate the vegetative growth, yield, and changes in floricane leaf nutrient concentration of two blackberry cultivars for three seasons in southern Brazil in response to annual $\mathrm{K}$ treatments.

\section{Material and Methods}

Study site. The research was conducted at Embrapa Clima Temperado in Rio Grande do Sul, Southern Brazil (lat. $31^{\circ} 40^{\prime} 46.98 \mathrm{~S}$, long. 52 $26^{\prime} 4.36 \mathrm{~W}$ ). In 2009, 2010, and 2011, the natural occurrence of chill hours $\left(\leq 7.2{ }^{\circ} \mathrm{C}\right)$ was 440,357 , and $361 \mathrm{~h}$, respectively. In $2008,0.25 \mathrm{t} \cdot \mathrm{ha}^{-1}$ of lime, 150 $\mathrm{kg} \cdot \mathrm{ha}^{-1}$ of $\mathrm{P}_{2} \mathrm{O}_{5}$, and $30 \mathrm{~kg} \cdot \mathrm{ha}^{-1}$ of $\mathrm{K}_{2} \mathrm{O}$ were incorporated $0.2 \mathrm{~m}$ deep three months before planting based on soil analysis (depth of 0-20 cm) and nutrient management guidelines (CQFS-RS/SC, 2004). In 2009, one year after planting, the soil had the following characteristics: sandy soil $(>70 \%), \mathrm{pH} 5.9, \mathrm{MO}$ $1.1 \%$, K $58.0 \mathrm{~g} \cdot \mathrm{m}^{-3}$, P $24.0 \mathrm{~g} \cdot \mathrm{m}^{-3}$, Ca 0.018 $\mathrm{mmol} \cdot \mathrm{m}^{-3}$, Mg $0.010 \mathrm{mmol} \cdot \mathrm{m}^{-3}$, B $0.2 \mathrm{~g} \cdot \mathrm{m}^{-3}$, $\mathrm{Cu} 0.6 \mathrm{~g} \cdot \mathrm{m}^{-3}, \mathrm{Na} 6.0 \mathrm{~g} \cdot \mathrm{m}^{-3}, \mathrm{Mn} 2.1 \mathrm{~g} \cdot \mathrm{m}^{-3}$, and $\mathrm{Zn} 0.6 \mathrm{~g} \cdot \mathrm{m}^{-3}$.

Plant material. One-year-old 'Tupy' and 'Xavante' blackberry plants were obtained from a commercial nursery (Frutplan, Pelotas, RS, Brazil) and transplanted in Sept. 2008 at a spacing of $0.5 \mathrm{~m}$ between plants and $3 \mathrm{~m}$ between rows (6667 plants per hectare). Grass alleyways ( $2 \mathrm{~m}$ wide) were showed and kept mowed between the rows. Plants were irrigated only in the first year from Sept. 2008 to Jan. 2009 as needed, using a single lateral drip tube. Plants of 'Tupy' (semierect) and 'Xavante' (erect) were not trained. To keep the canes erect, the primocanes were pruned to $1.20 \mathrm{~m}$ in height during the growing period (spring-summer). After harvesting, the old floricanes were cut at soil level. Both cultivars are low-chill blackberries, requiring 200-300 chill hours $\left({ }^{<} 7.2{ }^{\circ} \mathrm{C}\right)$.

Fertilizer treatments. Five $\mathrm{K}$ treatments were applied to plants during the first three years (2009-11). The fertilizer treatments after planting were: 0.0 (no K fertilizer application), 2.1, 4.2, 6.2, and $8.3 \mathrm{~g} /$ plant of elemental $\mathrm{K}$ (equivalent to $0.0,13.8,27.7$, 41.5 or $55.3 \mathrm{~kg} \cdot \mathrm{ha}^{-1}$, respectively). The rate of $4.2 \mathrm{~g} /$ plant or $27.7 \mathrm{~kg} \cdot \mathrm{ha}^{-1}$ corresponds to the current recommendation in Brazil (CQFS-RS/ $\mathrm{SC}, 2004)$. The rates $0.0,2.1,4.2,6.2$ and $8.3 \mathrm{~g}$ of elemental $\mathrm{K}$ correspond to $0.0,2.5,5.0,7.5$, and 10.0 of $\mathrm{g} /$ plant of $\mathrm{K}_{2} \mathrm{O}$, respectively. In addition to the $\mathrm{K}$ rates (treatments), all plots were fertilized with $5 \mathrm{~g} /$ plant $\left(33.3 \mathrm{~kg} \cdot \mathrm{ha}^{-1}\right)$ of $\mathrm{P}$ and $15 \mathrm{~g} / \mathrm{plant}\left(100 \mathrm{~kg} \cdot \mathrm{ha}^{-1}\right)$ of N. A single application of $\mathrm{P}$ and $\mathrm{K}$ was made at the beginning of budbreak and before flowering on 26 Aug. 2009, 9 Sept. 2010, and 22 Sept. 2011. The $\mathrm{N}$ was split into three applications; the first was made together with $\mathrm{P}$ and $\mathrm{K}$, the second $15 \mathrm{~d}$ after the first, and the third $30 \mathrm{~d}$ after the first. The sources of $\mathrm{K}$,
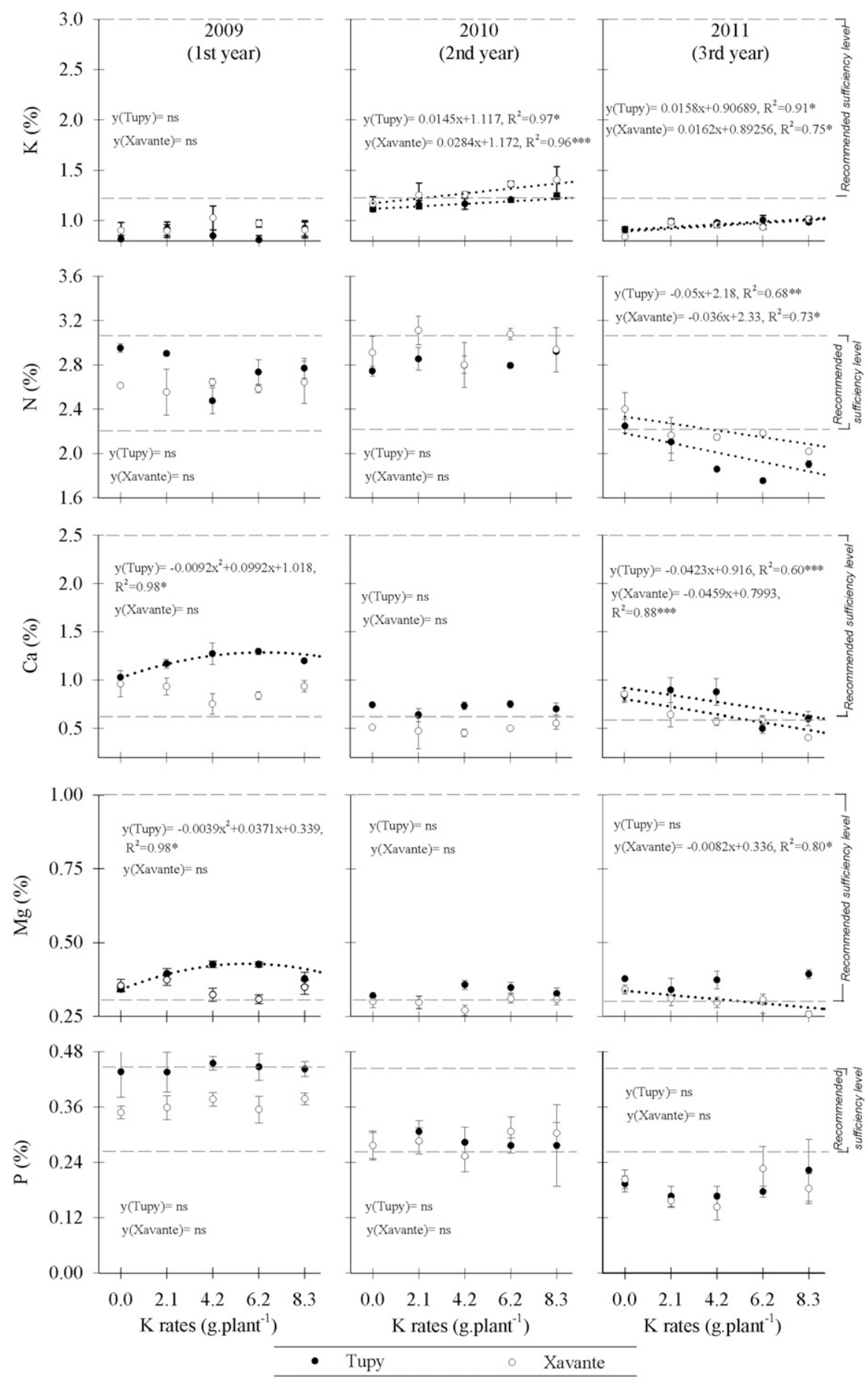

Fig. 1. Effect of potassium $(K)$ rates on floricane leaf concentration of $K$, nitrogen $(N)$, calcium $(\mathrm{Ca})$, magnesium (Mg), and phosphorus (P) in 'Tupy' and 'Xavante' blackberries during the first (2009), second (2010), and third (2011) year after planting. Plants were fertilized each spring with 0.0, 2.1, 4.2, 6.2 , or $8.3 \mathrm{~g} / \mathrm{plant}$ of K. Recommended sufficiency level according to CQFS-RS/SC (2004). Means $\pm \mathrm{SE}$, $\mathrm{n}=4 .{ }^{\mathrm{Ns}}, *, * *, * *$ Nonsignificant and significant at $P<0.05, P<0.01$, and $P<0.001$, respectively.

$\mathrm{N}$, and $\mathrm{P}$ were $\mathrm{KCl}$, ammonium sulfate $\left[\left(\mathrm{NH}_{4}\right)_{2} \mathrm{SO}_{4}\right]$, and triple superphosphate $\left[\mathrm{Ca}\left(\mathrm{H}_{2} \mathrm{PO}_{4}\right)_{2}\right]$, respectively.

Fruit were harvested two or three times per week in November, December, and January in 2009-10, 2010-11, and 2011-12. Fruit number and fruit mass were recorded from each of four plots of each treatment in 2009-10, 2010-11, and 2011-12. Plant height $(\mathrm{m})$ and cane density (canes. $\mathrm{m}^{-1}$ ) were measured for all plants from each of four plots in Dec. 2010. Dry pruning biomass (dried at $65{ }^{\circ} \mathrm{C} ; \mathrm{g} /$ plant) was determined in Aug. 2011; tip canes, broken and dead canes, and side branches were pruned to $25-30 \mathrm{~cm}$. Thinning was not needed. Chlorophyll index was measured with a chlorophyll meter (ClorofiLOG-Falker Automation Agrícola Ltda, Porto Alegre, Rio Grande do Sul, Brazil) using a random 50-mature leaf 
Table 1. Meteorological data of maximum and minimum temperature $\left({ }^{\circ} \mathrm{C}\right)$, precipitation $(\mathrm{mm})$ and chill hours $\left(<7.2^{\circ} \mathrm{C}\right)$ at Embrapa Clima Temperado during 2009-11.

\begin{tabular}{|c|c|c|c|c|c|c|c|c|c|c|c|c|c|c|c|}
\hline $\begin{array}{l}\text { Climatic } \\
\text { variables }^{z}\end{array}$ & Yr & Jan. & Feb. & Mar. & Apr. & May & June & July & Aug. & Sept. & Oct. & Nov. & Dec. & $\begin{array}{l}\text { Rainfall after } \\
\text { treatments }^{\mathrm{y}}\end{array}$ & Average/total \\
\hline & 2009 & 27.5 & 27.5 & 26.2 & 24.7 & 21.4 & 16.4 & 14.7 & 19.8 & 18.1 & 21.0 & 24.4 & 25.6 & & 22.3 \\
\hline & 2010 & 27.5 & 28.3 & 26.5 & 23.5 & 19.4 & 17.6 & 18.3 & 18.0 & 20.1 & 22.4 & 25.3 & 29.6 & & 23.0 \\
\hline \multirow{4}{*}{$\begin{array}{l}\text { Maximum } \\
\text { temperature }\left({ }^{\circ} \mathrm{C}\right)\end{array}$} & 2011 & 30.6 & 28.3 & 26.6 & 24.3 & 20.3 & 16.4 & 15.4 & 16.0 & 18.8 & 24.9 & 25.4 & 24.9 & & 22.7 \\
\hline & Normal $^{\mathrm{x}}$ & 29.2 & 28.3 & 27.4 & 24.2 & 21.1 & 18.6 & 17.9 & 18.8 & 20.0 & 21.9 & 24.5 & 27.3 & & 23.3 \\
\hline & 2009 & 17.8 & 18.4 & 17.9 & 14.3 & 11.8 & 7.8 & 6.1 & 10.3 & 12.6 & 11.9 & 17.6 & 17.7 & & 13.7 \\
\hline & 2010 & 19.3 & 19.6 & 17.9 & 14.0 & 12.5 & 9.6 & 8.5 & 8.4 & 12.3 & 11.4 & 13.2 & 16.6 & & 13.6 \\
\hline \multirow{5}{*}{$\begin{array}{l}\text { Minimum } \\
\text { temperature }\left({ }^{\circ} \mathrm{C}\right)\end{array}$} & 2011 & 19.7 & 19.0 & 16.5 & 14.1 & 11.0 & 8.7 & 7.8 & 8.4 & 9.1 & 12.3 & 14.0 & 15.0 & & 13.0 \\
\hline & Normal & 17.5 & 17.6 & 16.6 & 12.7 & 10.2 & 8.5 & 7.2 & 8.2 & 10.1 & 12.3 & 13.8 & 15.3 & & 12.5 \\
\hline & 2009 & 590.8 & 184.1 & 147.6 & 0.4 & 93.1 & 72.4 & 50.0 & 173.2 & 177.8 & 85.0 & 398.0 & 95.5 & 463.1 & 2067.9 \\
\hline & 2010 & 65.5 & 216.4 & 67.5 & 119.9 & 180.7 & 132.0 & 185.4 & 47.0 & 142.6 & 19.1 & 63.2 & 49.9 & 129.3 & 1289.2 \\
\hline & 2011 & 75.3 & 85.8 & 167.1 & 89.0 & 96.8 & 101.5 & 105.0 & 110.4 & 78.9 & 76.5 & 59.8 & 56.0 & 217.2 & 1102.1 \\
\hline \multirow[t]{4}{*}{ Precipitation (mm) } & Normal & 131.0 & 149.0 & 116.0 & 108.0 & 110.0 & 128.0 & 113.0 & 138.0 & 141.0 & 128.0 & 68.0 & 77.0 & & 1407.0 \\
\hline & 2009 & & & & & 9.0 & 118.0 & 186.0 & 26.0 & 18.0 & & & & & 357.0 \\
\hline & 2010 & & & & & 0.0 & 56.0 & 159.0 & 133.0 & 13.0 & & & & & 361.0 \\
\hline & 2011 & & & & & 0.0 & 111.0 & 171.0 & 107.0 & 62.0 & & & & & 451.0 \\
\hline \multirow[t]{4}{*}{ Chill hours $\left(<7.2^{\circ} \mathrm{C}\right)$} & Normal & & & & & 32.0 & 85.0 & 123.0 & 68.0 & 34.0 & & & & & 342.0 \\
\hline & Dormancy & & & & & & & & & & & & & & \\
\hline & Bud break & & & & & & & & & & & & & & \\
\hline & Flowering & & & & & & & & & & & & & & \\
\hline Phenological stage ${ }^{\mathrm{w}}$ & Harvest & & & & & & & & & & & & & & \\
\hline
\end{tabular}

${ }^{\mathrm{z}}$ Meteorological data were obtained from a nearby weather station.

${ }^{y}$ Total rainfall during the period between $\mathrm{K}$ treatment application and leaf collection for nutritional analysis.

${ }^{\mathrm{x}}$ Historical averages (1984-2010).

wPhenological stages of 'Tupy' and 'Xavante' blackberries in southern Brazil.
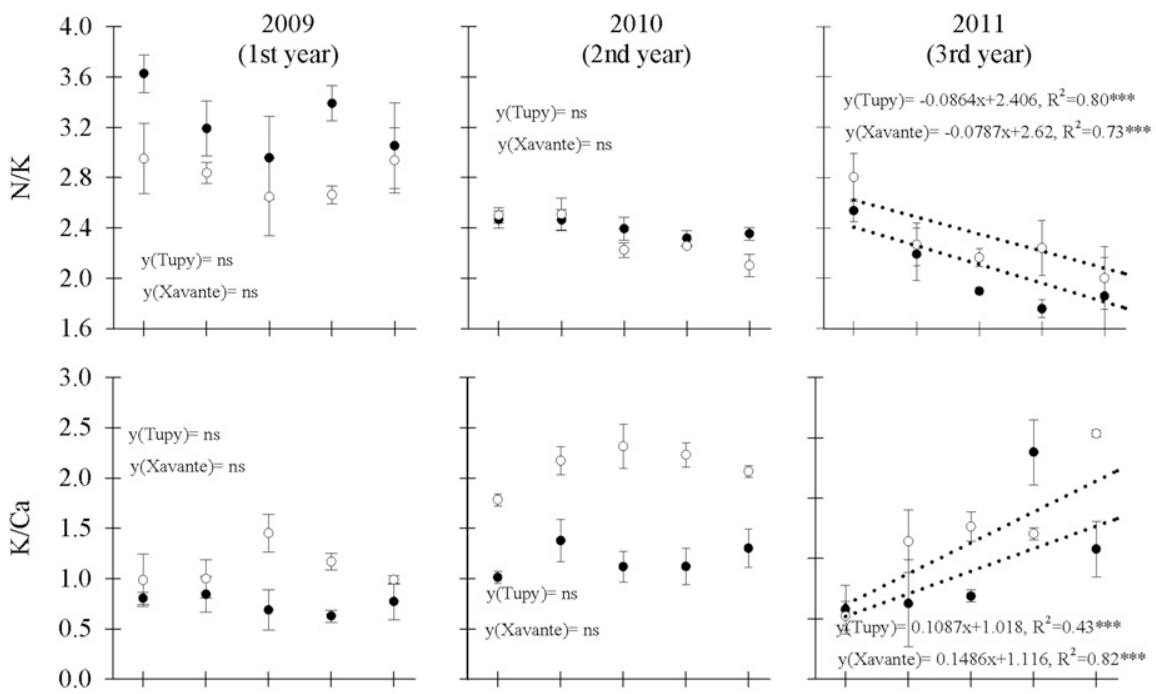
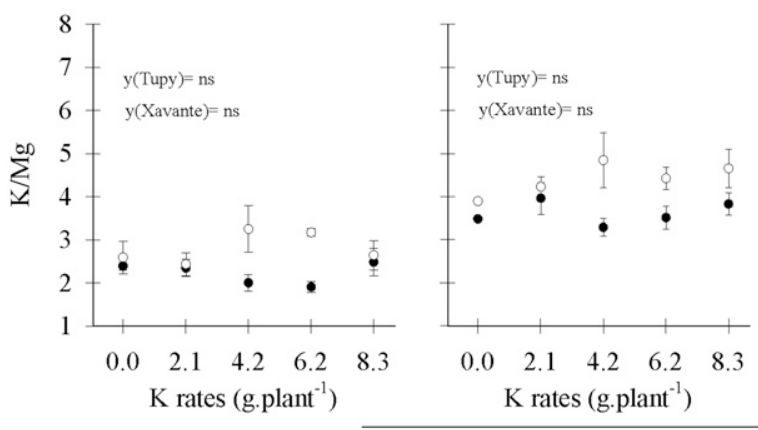

- Tupy

Xavante

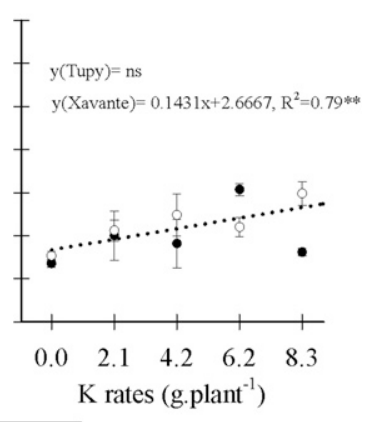

Fig. 2. Effect of potassium $(\mathrm{K})$ rates on the nitrogen $(\mathrm{N}) / \mathrm{K}, \mathrm{K} /$ calcium $(\mathrm{Ca})$, and $\mathrm{K} / \mathrm{magnesium}(\mathrm{Mg})$ ratios in floricane leaves in 'Tupy' and 'Xavante' blackberries during the first (2009), second (2010), and third (2011) year after planting. Plants were fertilized each spring with $0.0,2.1,4.2,6.2$, or $8.3 \mathrm{~g} / \mathrm{plant}$ of K. Means $\pm \mathrm{SE}$, $\mathrm{n}=3{ }^{\mathrm{Ns}}, *, * *, * * *$ Nonsignificant and significant at $P<0.05, P<0.01$, and $P<0.001$, respectively.

sample in Nov. 2011. Macro (N, P, K, Ca, and $\mathrm{Mg}$ ) and micronutrient [copper $(\mathrm{Cu}), \mathrm{Fe}$, $\mathrm{Mn}$, and $\mathrm{Zn}$ ] concentrations were determined from the sixth leaf (fully expanded) from the

apex of floricanes in the second half of November in 2009, 2010, and 2011, which corresponded to the beginning of harvest for the studied cultivars.
Experimental design. The experiment consisted of five $\mathrm{K}$ rates and two cultivars distributed in four completely randomized blocks that were evaluated for three years. Each plot consisted of five plants, and the middle three were evaluated to eliminate border effects. Data were analyzed by analysis of variance (ANOVA), and variables with significant differences for $\mathrm{K}$ rates were subjected to regression analysis.

\section{Results and Discussion}

Leaf nutrient status. In 2009, K rates did not influence the $\mathrm{K}$ leaf concentration in either cultivar (Fig. 1). Floricane leaf K concentrations in both cultivars were lower than what is considered sufficient for optimal growth in blackberry $(1.25 \%$ to $3.00 \%$; CQFS-RS/SC, 2004; Freire et al., 2007). In 2010 and 2011, leaf $\mathrm{K}$ concentration of both cultivars showed a linear increase in response to $\mathrm{K}$ application. Normal leaf $\mathrm{K}$ levels were only observed in 2010, and were seen in 'Tupy' at a $\mathrm{K}$ rate of $8.3 \mathrm{~g} / \mathrm{plant}$ and in 'Xavante' at $2.1 \mathrm{~g} /$ plant. Although there was a response to fertilization in 2011 , leaf $\mathrm{K}$ levels were below the recommendation of $1.25 \%$. Leaf $\mathrm{K}$ levels were between $0.88 \%$ and $1.03 \%$ in 'Tupy' and $0.86 \%$ and $1.01 \%$ in 'Xavante', indicating that optimal leaf $\mathrm{K}$ concentration in floricanes can be less than $1.25 \%$, between 0.80 and $1.0 \%$.

According to Hart et al. (2006), high K concentration in soil and low levels in the tissue may indicate a subsoil poor in $\mathrm{K}$, inadequate irrigation, diseases, or other production problems. In the present work, no problems with disease or low levels of $\mathrm{K}$ in the subsoil were observed. But the low levels of leaf K may be related to soil moisture (only rainfall) and high yield of the plants. In the period between $\mathrm{K}$ treatment application and leaf collection for nutritional analysis, 463.1, 

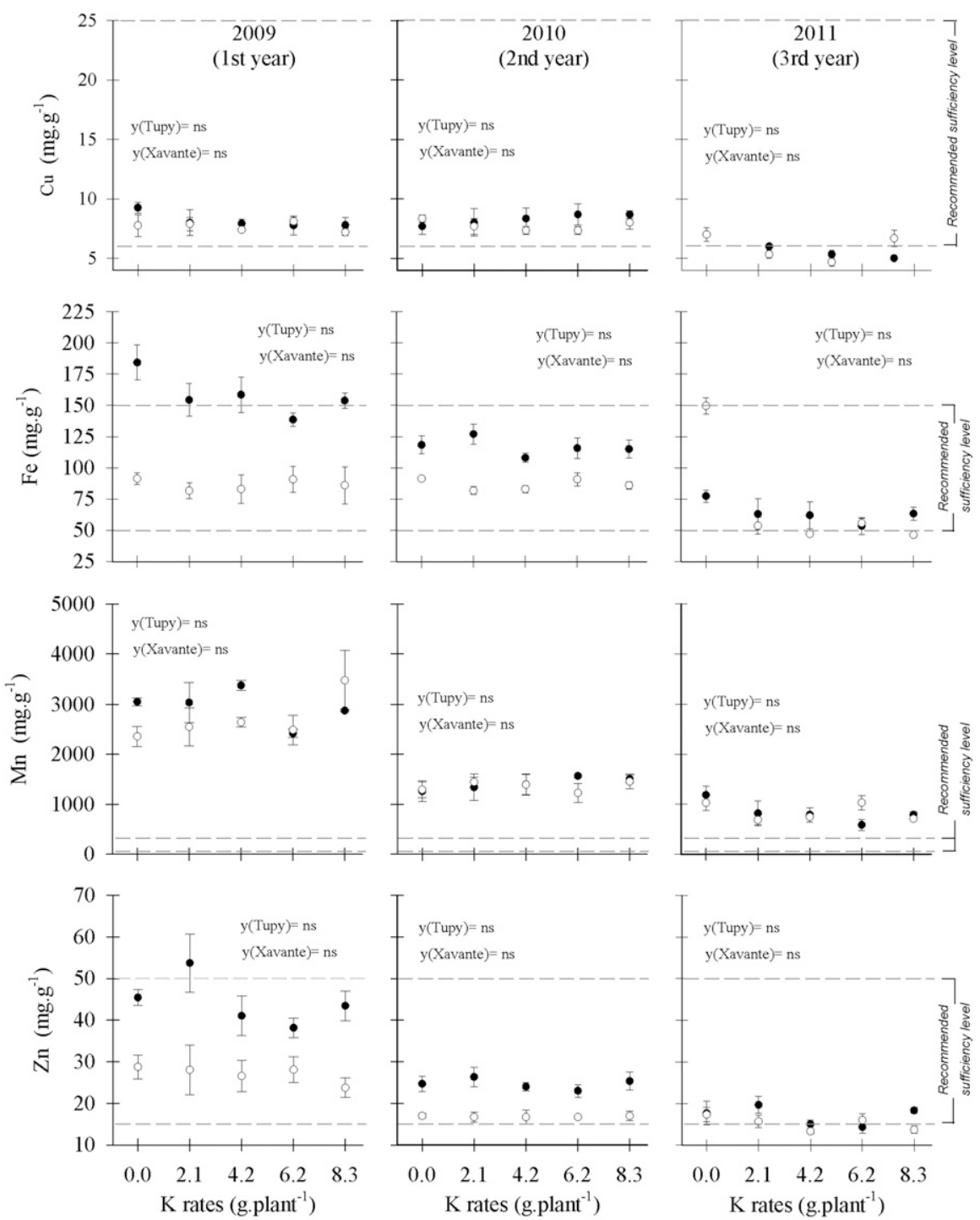
$\mathrm{K}$ rates (g.plant ${ }^{-1}$ )

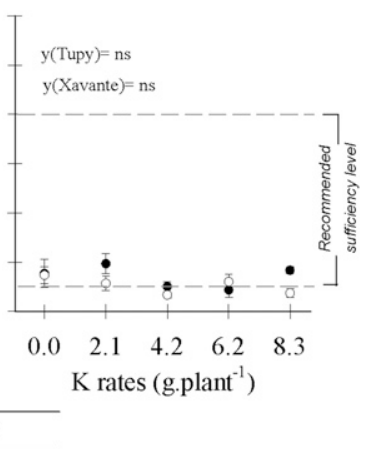

$$
\text { - Tupy } \circ \text { Xavante }
$$

Fig. 3. Effect of potassium $(\mathrm{K})$ rates on floricane leaf concentration of copper $(\mathrm{Cu})$, iron $(\mathrm{Fe})$, manganese (Mn), and zinc ( $\mathrm{Zn})$ in 'Tupy' and 'Xavante' blackberries in the first (2009), second (2010), and third (2011) year after planting. Plants were fertilized each spring with $0.0,2.1,4.2,6.2$, or $8.3 \mathrm{~g} / \mathrm{plant}$ of K. Recommended sufficiency level according to CQFS-RS/SC (2004). Means $\pm \mathrm{SE}, \mathrm{n}=3$. s, * * **, ***Nonsignificant and significant at $P<0.05, P<0.01$, and $P<0.01$, respectively.

129.3, and $217.2 \mathrm{~mm}$ rainfall were recorded in 2009, 2010, and 2011, respectively (Table 1). These volumes correspond to $22 \%, 10 \%$, and $20 \%$ of water that plants received throughout the year in 2009, 2010, and 2011, respectively. Thus, it is likely that the large volume of rain, especially in 2009 and 2011, may have contributed to leaching losses in view of the high solubility of $\mathrm{KCl}$. Furthermore, productivity was considered high (up to 15 $\mathrm{t} \cdot \mathrm{ha}^{-1}$ ), as the plants had no trellising system and were pruned to $1.20 \mathrm{~m}$ in height in the winter, suggesting that there may have been a major uptake of $\mathrm{K}$ by the fruit. In a study investigating nutrient uptake of fruit and leaves and canes removed in winter and postharvest pruning in raspberry, Pereira et al. (2013a) reported a total extraction of $14.35 \mathrm{~kg} \cdot \mathrm{ha}^{-1} \mathrm{~K}$ in Tupy and $12.29 \mathrm{~kg} \cdot \mathrm{ha}^{-1} \mathrm{~K}$ in Xavante cultivars. According to Harkins et al. (2014), the total amount of $\mathrm{K}$ removed by the fruit in cultivars Black Diamond and Marion averaged 12 to $27 \mathrm{~kg} \cdot \mathrm{ha}^{-1}$ in the third year after planting. The same authors also observed a high total removal of $\mathrm{K}$ in the floricanes ( 23 to $58 \mathrm{~kg} \cdot \mathrm{ha}^{-1}$ ) which was twice the amount seen in the fruit, indicating large quantities of $\mathrm{K}$ are removed each year as a result of fruit harvest and floricane pruning in the winter. Thus, $\mathrm{K}$ uptake by fruit formation and pruning as well as leaching losses may have contributed to the low concentration observed in floricane leaves at the beginning of the harvest.

For the $\mathrm{K}$ content of the soil in this study (58.0 $\mathrm{g} \cdot \mathrm{m}^{-3}$ ), current Brazilian recommendations indicate the application of $4.2 \mathrm{~g} /$ plant of K $\left(27.7 \mathrm{~kg} \cdot \mathrm{ha}^{-1}\right)$. But even with an application rate of $8.3 \mathrm{~g} /$ plant, leaf $\mathrm{K}$ content did not reach the recommended level for optimal growth in 2 of the 3 years of the study. Previous blackberry research (Hart et al., 2006) indicated it was necessary to apply up to $112 \mathrm{~kg} \cdot \mathrm{ha}^{-1}$ of $\mathrm{K}$, two times the highest rate in this study $(8.3 \mathrm{~g} /$ plant or 55.3 $\mathrm{kg} \cdot \mathrm{ha}^{-1}$ ), to raise leaf $\mathrm{K}$ concentration to recommended levels. These results indicate that current $\mathrm{K}$ fertilizer recommendations in Brazil are underestimated and there is a need for an update.

The leaf $\mathrm{N}$ concentrations in this study were considered normal for optimal growth (2.20\% to $3.00 \%$; CQFS-RS/SC, 2004; Freire, 2007) for blackberries in Brazil in the first and second year after planting (2009 and 2010), independent of the $\mathrm{K}$ rate (Fig. 1). However, in 2011, N leaf concentration decreased significantly in both cultivars in response to $\mathrm{K}$ rates (Fig. 1) including a decrease to levels considered below normal, especially in 'Tupy'. Without $\mathrm{K}$ fertilizer, leaf $\mathrm{N}$ concentrations averaged $2.25 \%$ and $2.40 \%$ in 'Tupy' and 'Xavante', respectively. On the other hand, at the highest $\mathrm{K}$ rate $(8.3 \mathrm{~g} / \mathrm{plant})$, 'Tupy' and 'Xavante' had only $1.90 \%$ and $2.01 \%$ leaf $\mathrm{N}$, respectively. It is possible that a $\mathrm{N}$ decrease in response to $\mathrm{K}$ rates occurred because $\mathrm{K}$ absorption increases demand of $\mathrm{N}$ (Castaño et al., 2008). The $\mathrm{N}$ demand may have been even greater because the concentration of organic matter in the soil was low $(1.1 \%)$ (CQFS-RS/SC, 2004; Freire, 2007), indicating low $\mathrm{N}$ availability to plants. In Fig. 2, the N/K ratio observed during the first year (2009) ranged from 2.66 to 3.62 , and was slightly higher in 'Tupy' than 'Xavante'. In the second year (2010), the N/K ratio was significantly lower, ranging from 2.10 to 2.50 , and was similar for both cultivars. However, in the third year (2011) a linear decrease in the $\mathrm{N} / \mathrm{K}$ ratio in both cultivars was again observed, with exception of the control $(0.0 \mathrm{~g}$ of $\mathrm{K}$ per plant). These results support the idea that a balance between fertilization with $\mathrm{K}$ and $\mathrm{N}$ is needed to maintain a balance between $\mathrm{K}$ and $\mathrm{N}$ in the plant and soil. Nelson and Martin (1986) studied effects of graduated rates of combined $\mathrm{N}$ and $\mathrm{K}$ on 'Thornless Evergreen' blackberry cultivated in soil with inadequate $\mathrm{K}$ concentration $\left(225 \mathrm{mg} \cdot \mathrm{kg}^{-1}\right)$, noting that higher levels of $\mathrm{N}$ and $\mathrm{K}$ increased leaf $\mathrm{N}$ but did not affect $\mathrm{K}$ concentration. According to these authors, moderate rates of both $\mathrm{N}$ and $\mathrm{K}$ produce the most desirable results. Castaño et al. (2008) reported an optimal ratio of $\mathrm{K} / \mathrm{N}$ application of 1.5 for blackberry. In a study investigating the effect of different $\mathrm{N}$ rates on leaf macro and micronutrient concentrations of 'Tupy' and 'Xavante' blackberries, Pereira et al. (2013b) observed a linear decrease in $\mathrm{K}$ leaf concentration in response to a linear increasing in $\mathrm{N}$ rates, also suggesting a close relationship between these elements. In general, the results of this study as well as others indicate that blackberry fertilization with $\mathrm{K}$ and $\mathrm{N}$ must be implemented in a balanced way. High application rates of only one of these nutrients may induce a deficiency in the other.

In 2009, Ca leaf concentration in both cultivars was considered normal for optimal growth in blackberry $(0.60 \%$ to $2.50 \%$; 

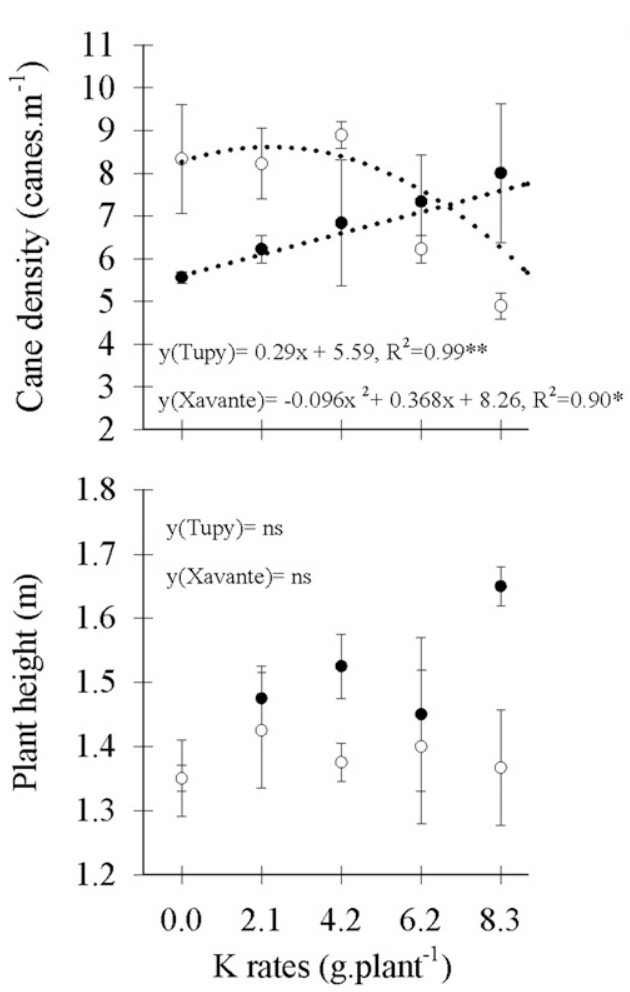

$\bullet \quad$ Tupy
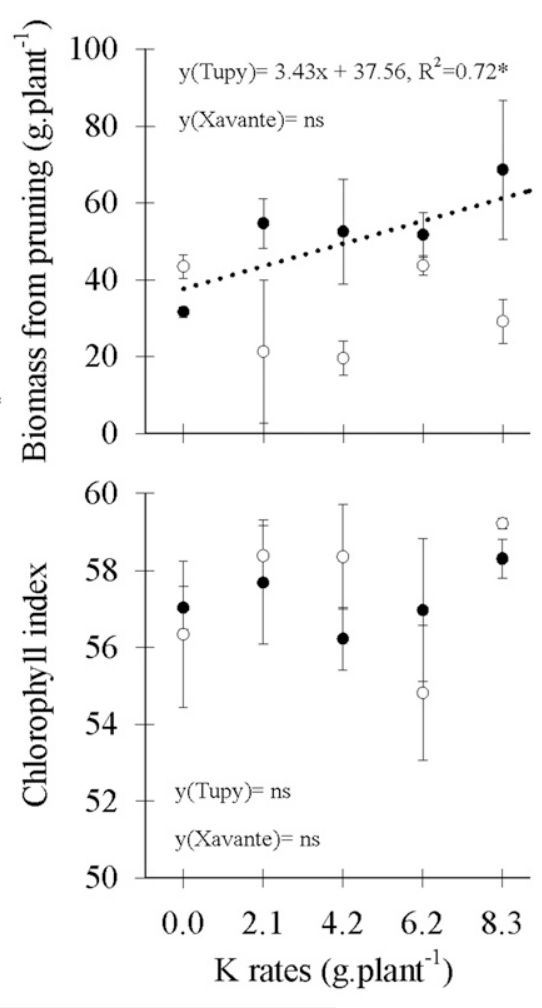

$0.14 \%$ and $0.23 \%$ in 2011 . In 2011, all leaf $P$ levels were classified as below normal for optimal growth $(0.26 \%$ to $0.45 \%$; CQFS-RS/ SC, 2004; Freire, 2007) regardless of K treatment. The reduction of $\mathrm{P}$ concentration over time was likely due to insufficient phosphate fertilization in the second and third years (2010 and 2011) of the study. Phosphorous fertilization was solely based on soil analysis, which indicated a high level of soil $\mathrm{P}\left(24.0 \mathrm{~g} \cdot \mathrm{m}^{-3}\right)(\mathrm{CQFS}-\mathrm{RS} / \mathrm{SC}, 2004)$. Therefore, only $5.0 \mathrm{~g}$ of $\mathrm{P}_{2} \mathrm{O}_{5}$ per plant $(33.33$ $\mathrm{kg} \cdot \mathrm{ha}^{-1}$ ) was applied each year. Thus, it is believed that due to the increasing production in the second and third years, there was an increase in the uptake of $\mathrm{P}$ and a reduction of available $\mathrm{P}$ in the soil. According to Pereira et al. (2013a), $P$ is the third most translocated element in 'Tupy' $(\mathrm{N}>\mathrm{K}>\mathrm{P})$ and the fourth in 'Xavante' $(\mathrm{N}>\mathrm{K}>\mathrm{Ca}>\mathrm{P})$, with fruit concentrations of $0.17 \%$ and $0.15 \%$, respectively. These levels were lower than that observed by Harkins et al. (2014), who reported $0.2 \% \mathrm{P}$ for Black Diamond and Marion cultivars. Considering the yield average of the treatments in this study, fruit water content average of $80 \%$, and the amount of nutrient uptake indicated by Pereira et al. (2013a), 'Tupy' took up 3.1, 4.0, and $4.1 \mathrm{~kg} \mathrm{P} / \mathrm{ha}$, while 'Xavante' took up 1.9, 2.7 , and $2.7 \mathrm{~kg} \mathrm{P} / \mathrm{ha}$ in 2009,2010 , and 2011 , respectively. Similar values were observed by Harkins et al. (2014), who reported P content ranging from 2.7 to $4.7 \mathrm{~kg} \cdot \mathrm{ha}^{-1}$ in 'Black Diamond' and 'Marion'. Harkins et al. (2014) also found that the total P extracted by fruit, primocanes, and floricanes ranged from 8 to $16 \mathrm{~kg} \cdot \mathrm{ha}^{-1}$. These values indicate that the rate applied in this study should have been sufficient for blackberry. The observed decrease in level of leaf P suggests inefficient management of Pfertilization. Several factors may have contributed to the low efficiency of applied $\mathrm{P}$ in this study. Surface application of $P$ has been shown to be less effective than subsurface banding due to lack of mobility of $P$ in the soil (Hart et al., 2006). Additionally, losses caused by leaching can be high, especially in sandy soils, which were used for this study (Faria and Pereira, 1993). Faria and Pereira (1993) suggest there is a need for a split application of $\left[\mathrm{Ca}\left(\mathrm{H}_{2} \mathrm{PO}_{4}\right)_{2}\right]$, which was not implemented in this study and is currently not recommended in Brazil. Therefore, it is believed that $\mathrm{P}$ was not adequately supplied by the fertilization management strategy recommended. Given the importance of leaf nutrient concentration as an indicator of plant health and nutritional status, the inadequate leaf nutrient levels observed in plants given recommended rates of nutrients in this study demonstrates a serious problem with current Brazilian recommendations.

In general, micronutrient leaf concentration $(\mathrm{Cu}, \mathrm{Fe}, \mathrm{Mn}$, and $\mathrm{Zn})$ were unaffected by $\mathrm{K}$ fertilizer rate (Fig. 3). In 2009 and 2010 , leaf $\mathrm{Cu}$ concentrations were considered normal for optimal growth (6 to 25 $\mathrm{mg} \cdot \mathrm{kg}^{-1}$; CQFS-RS/SC, 2004; Freire, 2007) for blackberries. However, in 2011, both cultivars, especially when fertilized with 

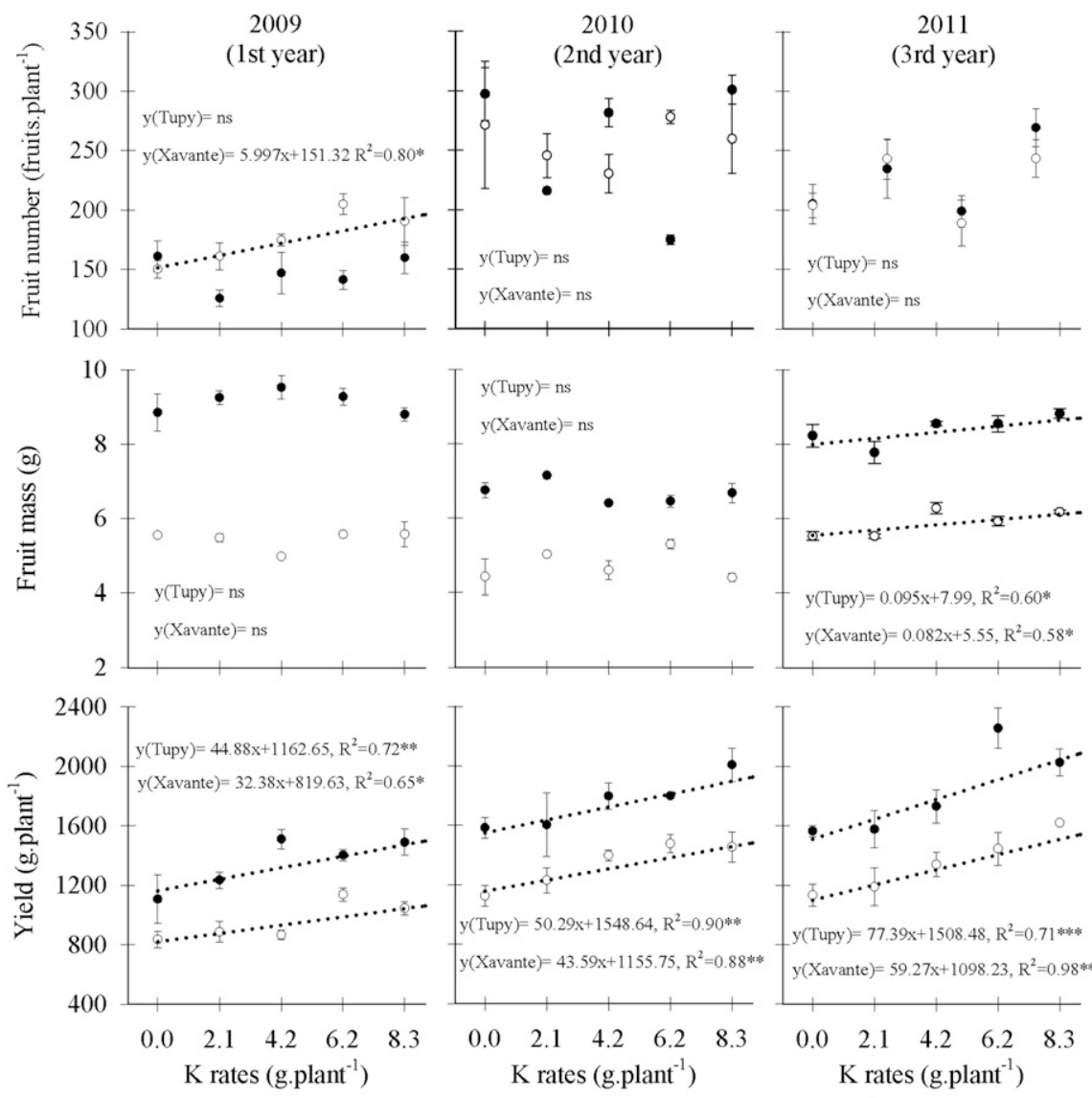

$\mathrm{K}$ rates (g.plant ${ }^{-1}$ )

- Tupy $\circ$ Xavante

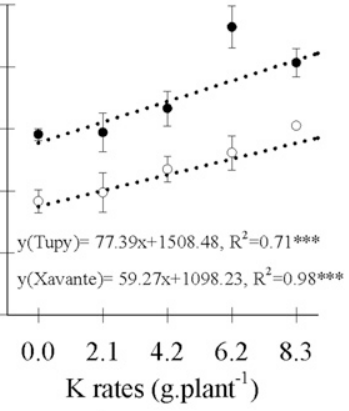

$\mathrm{K}$ rates (g.plant $\left.{ }^{-1}\right)$

Fig. 5. Effect of potassium (K) rates on fruit number, fruit mass, and yield of 'Tupy' and 'Xavante' blackberries during the first (2009), second (2010), and third (2011) year after planting. Plants were fertilized each spring with $0.0,2.1,4.2,6.2$, or $8.3 \mathrm{~g} / \mathrm{plant}$ of $\mathrm{K}$. Means $\pm \mathrm{SE}, \mathrm{n}=4$. ${ }^{\mathrm{N}}$, ${ }^{*}$, **, ***Nonsignificant and significant at $P<0.05, P<0.01$, and $P<0.001$, respectively.

$\mathrm{K}$, showed a trend of reduction of leaf $\mathrm{Cu}$, including some treatments with levels considered below normal (Fig. 3). Regarding $\mathrm{Fe}, \mathrm{Mn}$, and $\mathrm{Zn}$, there was a reduction in the levels of these elements over the three years of the study (Fig. 3). In the case of Fe and $\mathrm{Zn}$, some treatments had values considered below normal $\left(<50 \mathrm{mg} \cdot \mathrm{kg}^{-1}\right.$ to $\mathrm{Fe}$ and $<15$ $\mathrm{mg} \cdot \mathrm{kg}^{-1}$ to $\mathrm{Zn}$; CQFS-RS/SC, 2004; Freire, 2007 ) in 2011. In contrast, Mn values were considered excessive $\left(>1000 \mathrm{mg} \cdot \mathrm{kg}^{-1}\right.$; CQFS-RS/SC, 2004; Freire, 2007) in the first 2 years and above normal in 2011 (301 to $1000 \mathrm{mg} \cdot \mathrm{kg}^{-1}$; CQFS-RS/SC, 2004; Freire, 2007), especially in the treatments without $\mathrm{K}$ fertilization. According to Hue and Mai (2002), Mn toxicity is often more common than Mn deficiency, especially in acidic soils. This is because the solubility and availability of soil $\mathrm{Mn}$ is increased many fold by low $\mathrm{pH}$. Thus, the high Mn concentrations seen in leaves of 'Tupy' and 'Xavante' are likely due to the acidic $\mathrm{pH}$ (pH 5.9) associated with high levels of Mn in the soil in this experiment. It was also observed that in the first two years, 'Tupy' showed higher $\mathrm{Fe}$ and $\mathrm{Zn}$ contents than 'Xavante'.

Vegetative growth. Potassium rates influenced pruning biomass and cane density.
'Tupy' showed a linear increase in biomass in response to $\mathrm{K}$ fertilization, whereas 'Xavante' was not influenced (Fig. 4). Cane density varied with cultivar. 'Tupy' showed a linear increase in density up to $8.3 \mathrm{~g}$ of $\mathrm{K}$ per plant, whereas 'Xavante' peaked in cane density at $4.2 \mathrm{~g} /$ plant (Fig. 4).

The increases in pruning biomass and cane density in 'Tupy' were probably due to the structural and metabolic role of K, which induces increased photosynthesis and vegetative growth (Xu et al., 2011). In a study of symptoms of nutritional deficiency in blackberry, Antunes et al. (2014) observed that K deficiency caused a decrease in biomass in 'Tupy'. The response relative to pruning biomass (evaluated in 2011) likely occurred because of fertilizer application from the previous year (2010). Biomass was pruned in Aug. 2011 (winter in the southern hemisphere), before $\mathrm{K}$ application in 2011 and consisted of pruning the tip of canes, broken and dead canes, and shortening of side branches. Cane density also was influenced by $\mathrm{K}$ fertilization in 2010 , which was measured three months after $\mathrm{K}$ application. In this case, the observed density reflected the influence of cultivar and $\mathrm{K}$ rate, as canes were not thinned. Unlike results seen in 'Tupy', cane density in 'Xavante' showed a negative effect of elevated rates of $\mathrm{K}$ ( 6.2 and $8.3 \mathrm{~g} / \mathrm{plant})$, which may be related to the trend of decreasing $\mathrm{N} / \mathrm{K}$ ratio seen in 2011 that resulted in reduced leaf $\mathrm{N}$. In blackberry, $\mathrm{N}$ is the element used in largest quantities and plays major role in growth and development (Antunes et al., 2014; Crandall, 1995; Pereira, et al., 2013a; Strik, 2008).

Plant height and chlorophyll content did not respond to $\mathrm{K}$ rates (Fig. 4). Although increasing rates of $\mathrm{K}$ did not influence plant height in this study, Pereira et al. (2011), assessing $\mathrm{K}$ deficiency symptoms in 'Tupy' blackberry, found that $\mathrm{K}$ deficiency reduces growth, particularly in the stem. Thus, it can be inferred that independent of $\mathrm{K}$ application, soil $\mathrm{K}$ did not reach a deficient level. Pereira et al. (2011) also found no effect of available K on leaf chlorophyll content in 'Tupy'. Several studies have investigated the relationship between chlorophyll content and nutritional status of crops, but $\mathrm{N}$, as opposed to $\mathrm{K}$, has been shown to be most correlated to chlorophyll content (Pereira et al., 2013b).

In general, 'Tupy' showed a greater response to $\mathrm{K}$ fertilization than 'Xavante' in pruning biomass, plant height, and cane density(Fig. 4). Other studies conducted in southern Brazil, indicated that 'Tupy' is more vigorous than 'Xavante' (Antunes et al., 2014; Pereira et al., 2009; Pereira et al., 2013b).

Yield. Potassium rates influenced fruit number per plant only in 2009 and only in 'Xavante', where a linear increase in the number of fruits was observed with increasing $\mathrm{K}$ rates (Fig. 5). In 2009 in all treatments with $\mathrm{K}$, the number of fruit harvested in 'Xavante' was greater than in 'Tupy'. Although a short period of time passed between the treatments with $\mathrm{K}$ and the beginning of harvest, one hypothesis to support the increase that was seen in the number of fruit is the effect of $\mathrm{K}$ on the prevention of floral abortion. Physiological stress including mineral nutrient imbalance or deficiency, especially K, may contribute to abortion in pecan (Wood et al., 2009, 2010). This is supported by the data in Fig. 1, where leaf $\mathrm{K}$ concentration (year 2009) was insufficient. In addition, in 2011, the concentration of leaf $\mathrm{K}$ in both cultivars was also insufficient and although the response was not significant, there was a tendency toward an increase in the number of fruit in response to increasing $\mathrm{K}$ rates.

Fruit mass in 2009 and 2010 showed no effect of $\mathrm{K}$ fertilization (Fig. 5). In 2011 however, a linear response in fruit mass was observed with increasing $\mathrm{K}$ rates in both cultivars. Between cultivars, Tupy showed greater fruit mass than Xavante, as previously reported (Antunes et al., 2014; Pereira et al., 2009;). In a study of nutrient uptake (N not evaluated) in blackberry cultivars Tupy and Xavante, Pereira et al. (2013b) observed that $\mathrm{K}$ is the element with the highest uptake in the two cultivars, with 6.84 and $5.38 \mathrm{~kg} \cdot \mathrm{t}^{-1}$, respectively. This helps explain the significant effect of $\mathrm{K}$ fertilizer on fruit mass seen in both blackberry cultivars. In 2011, fruit mass 
increased from $8.2 \mathrm{~g}$ in the treatment with no $\mathrm{K}$ to $8.8 \mathrm{~g}$ in the $8.3 \mathrm{~g}$ of $\mathrm{K}$ per plant rate in 'Tupy', and from $5.5 \mathrm{~g}$ to $6.2 \mathrm{~g}$ in 'Xavante'.

Fruit yields in 'Tupy' and 'Xavante' were affected by $\mathrm{K}$ fertilization during the three years of this study. In all three years, yield increased linearly with an increase in $\mathrm{K}$ application (Fig. 5). Fertilizer recommendations for southern Brazil indicate that for soils with $58.0 \mathrm{~g} \cdot \mathrm{m}^{-3}$ of $\mathrm{K}$ (considered a medium level), $4.2 \mathrm{~g}$ of $\mathrm{K}$ should be applied per blackberry plant (CQFS-RS/SC, 2004). However, in the three years of this study, an increase in production was observed up to the rate of $8.3 \mathrm{~g}$ of $\mathrm{K}$ per plant, i.e., twice what is currently recommended, indicating that the current recommendation is low for optimal blackberry production. Pereira et al. (2013b) evaluated the response of cultivars Tupy and Xavante to $\mathrm{N}$ rates and found that the current recommendations for southern Brazil indicated rates sufficient for production of 'Xavante' but below the level required for 'Tupy'. This raises another issue with the current Brazilian fertilization recommendations for blackberry production that no distinction is made between cultivar groups of erect, semierect, and trailing blackberries.

'Tupy' had a greater yield than 'Xavante' in the three years of this study (Fig. 5) as has been previously reported (Antunes et al., 2014; Pereira et al., 2009; Pereira et al., 2013b; Pio et al., 2012). The higher yield seen in 'Tupy' may be due to its greater plant height (and thus greater fruit bearing surface), which is supported by a positive correlation $(r=0.86, P \leq 0.001)$ between yield and plant height. Fruit mass is another reason for the higher yield seen in 'Tupy', where fruit mass was $51 \%$ higher in 'Tupy' than in 'Xavante' during the three years of study. Moreover, fruit mass and fruit yield were positively correlated $(r=0.65, P \leq$ $0.001)$.

These problems with the current fertilization recommendations may be primarily because they were developed from recommendations from other countries. Generally for most fruit species, fertilizer recommendations have been problematic due to a lack of research. The situation is worse in the case of blackberries in Brazil, which have only recently gained economic importance (Antunes et al., 2014; Pereira et al., 2013b).

This is the first study of $\mathrm{K}$ nutrition in blackberry in Brazil. These data were used to investigate the reliability of current $\mathrm{K}$ recommendations for two major Brazilian blackberry cultivars. Our data indicates that the current $\mathrm{K}$ fertilizer recommendations are low, as floricane leaf $\mathrm{K}$ concentration were classified as below normal for optimal growth and yield continued to increase with greater $\mathrm{K}$ application even at twice the recommended rate.

\section{Literature Cited}

Antunes, L.E.C. 2002. Blackberry: A New Crop Option to Brazil. Cienc. Rural 32:151-158.

Antunes, L.E.C., E.D. Gonçalves, and R. Trevisan. 2010. Phenology and production of blackberry cultivars in agroecological system. Cienc. Rural 40:1929-1933.

Antunes, L.E.C., I.S. Pereira, L. Picolotto, G.K. Vignolo, and M.A. Gonçalves. 2014. Blackberry production in Brazil. Rev. Bras. Frutic. 36:100-111.

Botelho, R.V., A.P. Pavanello, D. Broetto, S.F. Scisloski, and T. Baldissera. 2009. Phenology and yield of thornless blackberry cv. Xavante in the region of Guarapuava-PR. Sci. Agr. 10:209-214.

Castaño, C.A.M., L.C.S. Morales, and M.F.H Obando. 2008. Evaluation of the nutritional deficiencies in the blackberry crop (Rubus glaucus) in controlled conditions for low mountainous forest. Agronomía. 16:75-88.

CQFS - Comissão de Química e Fertilidade do Solo - RS/SC. 2004. Manual de adubação e calagem para os estados do Rio Grande do Sul e Santa Catarina. 10th ed. Porto Alegre: SBCS-NRS.

Crandall, P.C. 1995. Bramble production. The management and marketing of raspberries and blackberries. Food Products Press, Binghamton, NY.

Fachinello, J.C., M.P.S. Pasa, J.D. Schmtiz, and D.B. Betemps. 2011. Situation and perspectives of temperate fruit crops in Brazil. Rev. Bras. Frutic. 33:109-120.

Faria, C.M.B. and J.R. Pereira. 1993. Movimento de fósforo no solo e seu modo de aplicação no tomateiro rasteiro. Pesq. agropec. bras. 28:1363-1370.

Freire, C.J. da S. 2007. Nutrição e adubação. Cultivo da amoreira-preta. (Sistemas de Produção, 12) Pelotas: Embrapa Clima Temperado. p. 45-54.

Harkins, R.H., B.C. Strik, and D.R. Bryla. 2014. Weed management practices for organic production of trailing blackberry, II. Accumulation and loss of biomass and nutrients. HortScience 49:35-43.

Hart, J., B. Strik, and H. Rempel. 2006. Caneberries. Nutrient management guide. Ore. State Univ. Ext. Serv., EM 8903-E.

Hue, N.V. and Y. Mai. 2002. Manganese toxicity in watermelon as affected by lime and compost amended to a hawaiian acid oxisol. HortScience 37:656-661.

Lee, J., M. Dossett, and C.D. Finn. 2012. Rubus fruit phenolic research: The good, the bad, and the confusing. Food Chem. 130:785-796.

Nelson, E. and L.W. Martin. 1986. The relationship of soil-applied $\mathrm{N}$ and $\mathrm{K}$ to yield and quality of 'Thornless Evergreen' blackberry. HortScience 21:1153-1154.
Pereira, I.S., C.A.P. Silveira, L. Picolotto, F.C. Schneider, M.A. Gonçalves, G.K. Vignolo, and L.E.C. Antunes. 2013a. Constituição química e exportação de nutrientes da amoreira-preta. Revista Congrega Urcamp 9:1-10.

Pereira, I.S., L. Picolotto, R.S. Messias, M.L. Potes, and L.E.C. Antunes. 2013b. Adubação nitrogenada e características agronômicas em amoreirapreta. Pesq. agropec. bras. 48:373-380.

Pereira, I.S., L.E.C. Antunes, C.A.P. Silveira, R.S Messias, J.P.P. Gardin, F.C. Schneider, and C.N. Pillon. 2009. Caracterização agronômica da amoreira-preta cultivada no Sul do Estado do Paraná. Documentos 271:1-19. Embrapa Clima Temperado, Pelotas.

Pereira, I.S., L.E.C. Antunes, J.C. Fachinello, R.S. Messias, C.A.P. Silveira, and G. Vignolo. 2011. Avaliações da subtração dos elementos N, P e K sobre o crescimento vegetativo da amoreirapreta. Comunicado Técnico 276, p. 1-8, Embrapa Clima Temperado, Pelotas.

Pio, R., A.A. Alvarenga, P.H.A. Moura, and P.N. Curi. 2012. Produção de amora-preta e framboesa em regiões de clima quente. Informe Agropecuário 33:46-55.

Raseira, M.C.B. and R.C. Franzon. 2012. Melhoramento genético e cultivares de amora-preta e mirtilo. Informe Agropecuário 33:11-20.

Rincon, T.A.R. and M.J.A. Salas. 1987. Influence of the levels of N, P, and $\mathrm{K}$ on the yield of blackberry. Acta Hort. 199:183-185.

Silva, J.T.A., I.P. Silva, A. Moura Neto, and E.L. Costa. 2008. Aplicação de potássio, magnésio e calcário em mudas de bananeira 'Prata-anã' (AAB). Rev. Bras. Frutic. 30:782-786.

Spiers, J.M. and J.H. Braswell. 2002. Influence of $\mathrm{N}, \mathrm{P}, \mathrm{K}, \mathrm{Ca}$, and $\mathrm{Mg}$ rates on leaf macronutrient concentration of 'Navaho' blackberry. Acta Hort. 585:659-663.

Strik, B.C. 2008. A review of nitrogen nutrition of Rubus. Acta Hort. 777:403-410.

Strik, B.C. and C.E. Finn. 2012. Blackberry production systems - a worldwide perspective. Acta Hort. 946:341-348.

Strik, B.C., J.R. Clark, C.E. Finn, and P. Bañados. 2007. Worldwide production of blackberries, 1995 to 2005 and predictions for growth. HortTechnology 17:205-213.

Vizzotto, M., M.C.B. Raseira, M.C. Pereira, and M.R. Fetter. 2012. Teor de compostos fenólicos e atividade antioxidante em diferentes genótipos de amoreira-preta (Rubus sp.). Rev. Bras. Frutic. 34:853-858.

Wood, B.W., L. Lombardini, and R. Heerema. 2009. Influence of aminoethoxyvinylglycine (AVG) on pecan fruit retention. HortScience 44:1884-1889.

Wood, B.W., L. Wells, and F. Funderburke. 2010. Influence of elevating tree potassium on fruit prop and yield of pecan. HortScience 45:911917.

Xu, W.Y., Y.T. Zou, A.M. Husaini, J.W. Zeng, L.L. Guan, Q. Liu, and W. Wu. 2011. Optimization of potassium for proper growth and physiological response of Houttuynia cordata Thunb. Environ. Expt. Bot. 71(2):292-297. 